JAMP: Jurnal Adminitrasi dan Manajemen Pendidikan

Volume 3 Nomor 4 Desember 2020, Hal : 314 - 319

Tersedia Online di http://journal2.um.ac.id/index.php/jamp/

ISSN 2615-8574 (online)

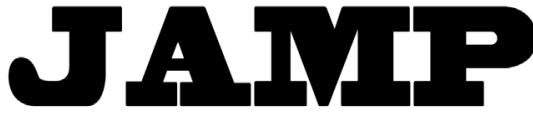

JURNAL ADMINISTRASI DAN MANAJEMEN PENDIDIKAN

\title{
PROFIL KARAKTER SEMANGAT KEBANGSAAN PADA SEKOLAH DASAR UMUM DAN KEAGAMAAN
}

\author{
Darmaji ${ }^{1}$ \\ Nurul Ulfatin ${ }^{2}$ \\ Mustiningsih $^{2}$ \\ ${ }^{1}$ SD Plus Al-Kautsar Kota Malang \\ ${ }^{2}$ Manajemen Pendidikan, Fakultas Ilmu Pendidikan, Universitas Negeri Malang \\ Jalan Semarang No. 5 Malang, Jawa Timur, Indonesia \\ E-mail: ajidarmaji64@gmail.com
}

\begin{abstract}
Students are currently experiencing a character crisis which is concerning. Cultivating the character value of the national spirit is one of the characters that must be formed. The purpose of this study is to examine more deeply the character profile of the national spirit in public and religious elementary schools. A qualitative approach with a multi-case research design was used in this study. The locations in this study were SDN Pandanwangi 3 Malang and SD Muhammadiyah 8 KH Mas Mansyur Malang. Data mining in this study used observation, interview, and documentation study techniques. The results of this study are (1) public elementary schools, focusing on character values on the character of the national spirit, while elementary schools with an Islamic background, inculcating religious and nationalist characters. (2) the character values chosen by the two schools are guided by the 5 main pillars of KDP, (3) the character values used are then integrated and combined with the vision, mission, and goals of the school, and (4) both schools have the goal of forming students who are has a homeland love personality.
\end{abstract}

Keywords: character education, character of national spirit, elementary school

\begin{abstract}
Abstrak: Peserta didik saat ini mengalami krisis karakter yang memprihatinkan Penanaman nilai karakter semangat kebangsaan menjadi salah satu karakter yang harus dibentuk. Tujuan dari penelitian ini yakni untuk mengkaji lebih dalam mengenai profil karakter semangat kebangsaan pada sekolah dasar umum dan keagamaan. Pendekatan kualitatif dengan rancangan penelitian multi kasus digunakan dalam penelitian ini. Lokasi dalam penelitian ini yaitu SDN Pandanwangi 3 Malang dan SD Muhammadiyah 8 KH Mas Mansyur Malang. Penggalian data dalam penelitian ini menggunakan teknik observasi, wawancara, dan studi dokumentasi. Hasil penelitian ini yakni (1) sekolah dasar negeri, memfokuskan nilai karakter pada karakter semangat kebangsaan, sementara sekolah dasar dengan latar belakang Islam, penanaman karakter religius dan nasionalis. (2) nilai karakter yang dipilih oleh kedua sekolah berpedoman pada 5 pilar utama PPK, (3) nilai karakter yang digunakan kemudian diintegrasikan dan dipadukan dengan visi, misi, dan tujuan sekolah, dan (4) Kedua sekolah memiliki tujuan yaitu membentuk peserta didik yang memiliki kepribadian cinta tanah air.
\end{abstract}

Kata kunci: pendidikan karakter, karakter semangat kebangsaan, sekolah dasar

Peserta didik sebagai generasi muda bangsa Indonesia yang dapat meningkatkan martabat dan jati diri bangsa saat ini mengalami krisis karakter yang memprihatinkan. Kepedulian terhadap sesama, toleransi, dan sikap positif lainya yang semakin tahun seakan hilang, menjadi kekhawatiran tersendiri (Indratmoko et al., 2019). Guna menumbuh kembangkan kembali karakter bangsa Indonesia yang semakin terkikis zaman, maka sekolah, tenaga pendidik dan masyarakat dituntut untuk berperan langsung dalam menangani masalah ini (Juharyanto et al., 2020). 
Lemahnya pemahaman tentang landasan filosofis dan historis terbentuknya bangsa ini menjadi suatu bentuk ketidakpedulian warga negara pada bangsanya sendiri. Berbagai persoalan yang terjadi, radikalisasi, perseteruan antar agama menjadi isu penting dan memerlukan upaya solutif (Parker, 2014; Raihani, 2011). Terutama dalam pendidikan yang diharapkan mampu untuk menciptakan generasi yang cerdas, berakhlak, dan demokratis dan berbagai aspek kehidupan memerlukan banyak dukungan untuk mentransformasi pengetahuan (Parker \& Raihani, 2011). Pentingnya upaya memperkuat jati diri bangsa menjadi faktor penting dalam pembangunan bangsa yang bermartabat.

Pendidikan karakter mutlak diperlukan dalam pendidikan dasar yang merupakan pintu masuk bagi sesorang untuk dapat melanjutkan perjalanan pada jenjang berikutnya (Hayudiyani et al., 2020). Hal tersebut didukung oleh pernyataan (Samani, 2011) yang memberikan makna bahwa karakter adalah nilai dasar yang dapat membangun diri seseorang karena dampak dari warisan budaya, keturunan maupun faktor lingkungan yang dapat membedakan antara orang satu dengan yang lain serta dilaksanakan dalam sikap dan tingkah laku keseharian. Sebagai sebuah pondasi, maka harus dibangun dengan kuat supaya mampu menahan gempuran, goncangan serta adanya terpaan arus perkembangan dan perubahan jaman. Penanaman nilai karakter semangat kebangsaan menjadi salah satu karakter yang harus dibentuk (Amir, 2013). Nilai semangat kebangsaan yang dimaksud adalah cara berpikir dan bertindak serta keluasan wawasan peserta didik akan pentingnya menjaga martabat bangsa dan negara.

Hasil penelitian sebelumnya, menunjukkan bahwa implementasi pendidikan semangat kebangsaan di sekolah yang berlatar belakang Islam dilakukan melalui pembiasaan dan pemberdayaan seluruh warga sekolah di samping fokus utamanya adalah penanaman karakter religius (Priyambodo, 2017), hal ini didukung oleh hasil penelitian (Fadlilatun, 2016) yang menyatakan penanaman karakter semangat kebangsaan di sekolah Islam melalui kedisiplinan, keteladanan guru, pembinaan siswa akan pentingnya menghormati Bendera Merah Putih bukanlah hal syirik. Penumbuhan karakter semangat kebangsaan siswa bisa dimulai dari pemahaman siswa serta guru dan wali murid terhadap landasan filosofis dan historis pembangunan suatu bangsa (Lestyarini, 2012).

Hasil observasi yang dilakukan menunjukkan bahwa SDN Pandanwangi 3 Malang dan SD Muhammadiyah $8 \mathrm{KH}$. Mas Mansyur Malang nilai utama yang dipilih yaitu pembentukan karakter semangat kebangsaan melalui pembiasaan dengan penanaman nilai-nilai agama dalam seluruh kegiatan di sekolah. Hal ini diperkuat dengan visi SDN Pandanwangi 3 Malang yaitu Terwujudnya insan berbudi pekerti, cerdas, terampil, mandiri, berlandaskan iman dan taqwa (IMTAQ), berbudaya dan peduli lingkungan. Hal yang sama juga dibuktikan dengan visi dari SD Muhammadiyah 8 KH. Mas Mansyur Malang yaitu Terwujudnya generasi qur'ani, berakhlaqul karimah, unggul dalam prestasi, berintegrasi, berkemajuan, dan berbudaya lingkungan

Berdasarkan visi tersebut dapat kita simpulkan bahwa dari dua lokasi tersebut memiliki tujuan utama untuk membentuk peserta didik menjadi generasi yang bermanfaat bagi bangsa dan negara dengan berfokus pada nilai keagamaan, berbudaya, dan demokrasi. Terbentuknya visi ini tentunya menjadi kebijakan yang diambil sekolah untuk dijadikan pedoman pelaksanaan kegiatan sekolah. Berdasarkan hal tersebut, maka dirasa menarik untuk meneliti dan mengkaji lebih dalam mengenai profil karakter semangat kebangsaan pada sekolah dasar umum dan keagamaan. Lokasi penelitian dipilih karena lembaga ini berhasil menjalankan dan membentuk karakter semangat kebangsaan bagi peserta didiknya secara efektif dan efisien.

\section{METODE}

Pendekatan kualitatif digunakan dalam penelitian ini, dengan rancangan penelitian yang digunakan yaitu multi kasus. Lokasi dalam penelitian ini yaitu SDN Pandanwangi 3 Malang dan SD Muhammadiyah $8 \mathrm{KH}$ Mas Mansyur Malang. Penggalian data dalam penelitian ini menggunakan teknik observasi berperan serta (participan observation), wawancara yang mendalam (in dept interview), dan studi dokumentasi. Key informan atau narasumber kunci dalam penelitian ini yaitu kepalas SDN Pandanwangi 3 Malang dan Kepala SD Muhammadiyah 8 KH Mas Mansyur Malang. Sumber data lain dari penelitian ini adalah kepala sekolah, guru kelas, guru mata pelajaran tambahan, kegiatan pembelajaran tambahan, 
serta dokumen sekolah yang relevan. Analisis data dalam penelitian ini melalui tiga tahapan yakni reduksi data, penyajian data dan penarikan kesimpulan. Kegiatan pengecekan keabsahan data dilakukan oleh peneliti untuk memvalidasi apakah data sudah akurat. Pengecekan keabsahan data dalam penelitian ini menggunakan uji kredibilitas, dalam penelitian ini uji kredibilitas meliputi triangulasi, perpanjangan waktu pengamatan, meningkatkan ketekunan, serta kecukupan bahan referensi.

\section{HASIL}

Karakter peserta didik yang ingin dibangun dan dibentuk di SDN Pandanwangi 3 Malang yakni dengan bagaimana sekolah menentukan nilai karakter utama yang dipilih untuk dilaksanakan melalui kegiatan yang terprogram selama satu tahun pembelajaran. Salah satunya melalui 5 pilar PPK, hal ini dilakukan sebagai landasan untuk membentuk kepribadian peserta didik. Salah satu nilai dalam 5 pilar PPK tersebut yakni nilai religius yang diterapkan sekolah melalui karakter semangat kebangsaan. Nilai karakter semangat kebangsaan juga dipilih sekolah yang kemudian akan dikembangkan dalam visi dan misi sekolah. Karakter semangat kebangsaan di sekolah ini juag terlihat dalam slogan, bendera merah putih dan garuda pancasila yang terdapat pada dinding ruang-ruang kelas. Hal ini merupakan salah satu bentuk upaya sekolah dalam memunculkan karakter semangat kebangsaan pada peserta didik. Dapat dilihat pula karakter semangat kebangsaan ini terintegrasi pada proses pembelajaran. Hal ini dilakukan karena tertuang pula pada Kurikulum Tingkat Satuan Pendidikan (KTSP).

Mengembangkan nilai karakter semangat kebangsaan yang berpedoman pada visi dan misi serta tujuan, pihak sekolah dalam menentukannya melalui proses diskusi dan rapat dengan kepala sekolah, guru, staf, dan komite sekolah. Berdasarkan paparan data di atas maka tujuan dan harapan sekolah yakni dapat mencetak generasi unggul yang cinta dan mampu melindungi bangsa dan tanah air dimasa yang mendatang. Selain itu, penanaman nilai karakter tidak hanya bertujuan untuk mencetak anak menjadi pribadi yang nasionalis, tetapi dengan nilai karakter semangat kebangsaan juga untuk mencetak anakanak yang memiliki akhlak yang baik, bertanggungjawab, beriman kepada Tuhan Yang Maha Esa dan memiliki karakter yang kuat.

Karakter peserta didik yang ingin dibangun dan dibentuk di SD Muhammadiyah 8 KH Mas Mansyur Malang yakni memilih 5 pilar utama nilai karakter PPK. Hal ini dilakukan karena sekolah ini merupakan sekolah yang didirikan oleh lembaga organisasi, sehingga untuk nilai karakter religius yang ditanamkan pada peserta didik menjadi hal pokok dan utama. Sama halnya dengan SDN Pandanwangi 3 Malang, sekolah ini juga memilih nilai karakter semangat kebangsaan untuk membangun dan membentuk karakter peserta didik. Dalam implementasinya, peserta didik harus menghafal dan mengerti sejarah dan nama pahlawan, tetapi tidak hanya itu banyak hal lain sebagai bentuk kegiatan dari karakter semangat kebangsaan.

Tahap penentuan nilai karakter dilakukan oleh pihak sekolah seperti kepala sekolah, guru, staf dan komite sekolah. Nilai karakter tertuang pada visi dan misi SD Muhammadiyah $8 \mathrm{KH}$ Mas Mansyur Malang yang kemudian dijadikan landasan untuk melakukan kegiatan bagi peserta didik. Dengan diintegrasikannya nilai karakter semangat kebangsaan maka menjadi suatu komitmen bagi sekolah untuk terus melakukan kegiatan yang menunjang rencana pelaksanaan nilai karakter semangat kebangsaan. Implementasi lain juga dilakukan dalam proses pembelajaran, hal ini terjadi karena guru merinci nilai karkater tersebut melalui RPP dan silabus. Berdasarkan paparan data di atas, diketahui bahwa penerapan nilai karakter semangat kebangsaan sekolah memiliki tujuan dan harapan agar peserta didik memiliki karakter positif untuk paham dan mengetahui sejarah dan makna dari cinta tanah air.

Berdasarkan paparan temuan di atas, diketahui bahwa SDN Pandanwangi 3 dan SD Muhammadiyah 8 KH Mas Mansyur Malang untuk menerapkan nilai karakter semangat kebangsaan yakni melalui nilai 5 pilar PPK yang kemudian dirancang ke dalam visi, misi dan tujuan sekolah. Untuk implementasi kegiatan dilakukan melalui pembiasaan-pembiasaan kegiatan pada proses pembelajaran. Hal ini diterapkan melalui proses perencanaan yang dilakukan secara bersama-sama kepala sekolah, guru, staf dan komite sekolah, yang kemudian guru merincinya pada RPP dan silabus. Tidak hanya itu, sekolah juga memasang slogan, bendera merah putih dan garuda pancasila sebagai bentuk simbolik dari nilai karakter semangat berkebangsaan. 


\section{PEMBAHASAN}

Peserta didik diharapkan untuk mampu memiliki wawasan tentang nilai dan pentingnya seseorang memiliki moral yang baik misalnya dalam pengambilan keputusan, melakukan penalaran, dan menyelesaikan masalah. Sehingga peserta didik dapat dengan menyeimbangkan antara kebutuhan, keinginan, dan Tindakan yang harus dilakukan (Pane \& Patriana, 2016). Tentunya, sikap yang demikian perlu diasah dan dibiasakan sehingga bisa menjadi suatu kebiasaan baik bagi peserta didik. Karakter peserta didik yang ingin dibangun dan dibentuk di SD Muhammadiyah 8 KH Mas Mansyur Malang yakni memilih 5 pilar utama nilai karakter PPK. Hal ini dilakukan karena sekolah ini merupakan sekolah yang didirikan oleh lembaga organisasi, sehingga untuk nilai karakter religius yang ditanamkan pada peserta didik menjadi hal pokok dan utama. Sama halnya dengan SDN Pandanwangi 3 Malang, sekolah ini juga memilih nilai karakter semangat kebangsaan untuk membangun dan membentuk karakter peserta didik.

Diketahui bahwa SDN Pandanwangi 3 dan SD Muhammadiyah 8 KH Mas Mansyur Malang untuk menerapkan nilai karakter semangat kebangsaan yakni melalui nilai 5 pilar PPK yang kemudian dirancang ke dalam visi, misi dan tujuan sekolah. Untuk implementasi kegiatan dilakukan melalui pembiasaan-pembiasaan kegiatan pada proses pembelajaran. Karakter semangat kebangsaan merupakan salah satu nilai karakter yang dikembangkan untuk membentuk karakter positif dalam diri peserta didik. Ada 18 nilai karakter yang ditetapkan oleh Kementerian Pendidikan dan Kebudayaan yaitu religius, jujur, toleransi disiplin, kerja keras, kreatif, mandiri, demokratis, rasa ingin tahu, semangat kebangsaan, cinta tanah air, menghargai prestasi, bersahabat/komunikatif, cinta damai, gemar membaca, peduli lingkungan, peduli sosial, dan tanggung jawab (Wibowo, 2013). Pengembangan pendidikan karakter semangat kebangsaan dilakukan di lembaga pendidikan yang terkandung pendidikan moral, budi pekerti, karakter dan nilai kehidupan.

Hal ini diterapkan melalui proses perencanaan yang dilakukan secara bersama-sama kepala sekolah, guru, staf dan komite sekolah, yang kemudian guru merincinya pada RPP dan silabus. Kepala sekolah memainkan peran penting dalam usaha mewujudkan lulusan yang berkarakter (Adha et al., 2019). Implementasi pendidikan karakter yang hanya dilakukan dengan memberikan pengetahuan dasar tidak akan berhasil tanpa adanya tindakan konkrit yang dilakukan secara kontinyu serta perbaikan yang terus dilakukan dalam setiap prosesnya (Mulyasa, 2013). Pendidikan karakter dapat dilakukan dengan mengintegrasikan nilai-nilai karakter dalam mata pelajaran dan program sekolah yang sudah direncanakan. (Maunah, 2015) menyimpulkan bahwa pembentukan karakter peserta didik dapat dilakukan melalui dua strategi, pertama yakni internal sekolah melalui proses belajar mengajar, kegiatan pembudayaan peserta didik, kegiatan pembiasaan peserta didik, dan kegiatan ekstrakurikuler dan kokurikuler, kedua eksternal sekolah yang meliputi lingkungan keluarga dan masyarakat.

Berdasarkan paparan data di atas, diketahui bahwa penerapan nilai karakter semangat kebangsaan sekolah memiliki tujuan dan harapan agar peserta didik memiliki karakter positif untuk paham dan mengetahui sejarah dan makna dari cinta tanah air. Karakter semangat kebangsaan ini diartikan sebagai cara berfikir, bertindak, dan berwawasan bangsa dan negara yang memposisikan sebagai suatu kepentingan diri dan kelompok (Muryatama, 2018). Tujuannya adalah untuk membentuk peserta didik yang mampu membela dan mencintai bangsa dan negaranya dan menjadi warga negara yang baik dan bijak. Mampu menempatkan kepentingan bangsa, agama, dan diri sendiri sebagai suatu kesatuan utuh untuk mencapai tujuan pendidikan nasional.

Tujuan pendidikan karakter sejatinya yaitu meningkatkan kualitas kehidupan peserta didik (Pane \& Patriana, 2016). Dengan adanya pendidikan karakter, sekolah dapat membekali peserta didik sehingga mereka siap untuk memberikan kontribusi pada lingkungan masyarakat. Peserta didik dikenalkan dengan nilai-nilai penting kehidupan diantaranya yaitu keimanan, ketaqwaan, kejujuan, kepedulian, bertanggung jawab, dan memiliki sikap toleransi (Parker \& Raihani, 2011). Sebuah lembaga pendidikan dianggap berhasil jika mampu mengembangkan potensi dan membangun karakter peserta didiknya sehingga mampu mendukung dan mendirikan bangsa dan negara yang bermartabat (Megawangi, 2010). 


\section{SIMPULAN}

Berdasarkan hasil penelitian dan pembahasan diketahui bahwa Sekolah dasar negeri, memfokuskan nilai karakter pada karakter semangat kebangsaan, sementara Sekolah dasar dengan latar belakang Islam, penanaman karakter religius dan nasionalis. Nilai karakter yang dipilih oleh kedua sekolah berpedoman pada 5 pilar utama PPK. Nilai karakter yang digunakan kemudian diintegrasikan dan dipadukan dengan visi, misi, dan tujuan sekolah melalui rapat dan koordinasi seluruh perangkat sekolah. Kedua sekolah secara konsep memiliki tujuan yang sama yaitu membentuk dan menciptakan peserta didik yang memiliki kepribadian cinta tanah air sehingga dapat menjaga keutuhan bangsa, menjadi warga negara yang baik, dan bangga terhadap negaranya. Karakter semangat kebangsaan merupakan salah satu nilai karakter yang dikembangkan untuk membentuk karakter positif dalam diri peserta didik. Pengembangan pendidikan karakter semangat kebangsaan dilakukan di lembaga pendidikan yang terkandung pendidikan moral, budi pekerti, karakter dan nilai kehidupan. Tujuannya yakni untuk membentuk peserta didik yang mampu mencintai bangsa dan negaranya dan menjadi warga negara yang baik dan bijak, serta mampu menempatkan kepentingan bangsa, agama, dan diri sendiri sebagai suatu kesatuan utuh.

\section{DAFTAR RUJUKAN}

Adha, M. A., Supriyanto, A., \& Timan, A. (2019). Strategi Peningkatan Mutu Lulusan Madrasah Menggunakan Diagram Fishbone. Tarbawi: Jurnal Keilmuan Manajemen Pendidikan, 5(01), 11-22. http://jurnal.uinbanten. ac.id/index.php/tarbawi/article/view/1794/1579

Amir, S. (2013). Pancasila as Integration Philosophy of Education And National Character. International Journal of Scientific and Technology Research, 2(1), 54-57.

Fadlilatun. (2016). Penanaman Karakter Semangat Kebangsaan Di Sd Unggulan Aisyiyah Bantul. Jurnal Pendidikan Guru Sekolah Dasar, 11, 1033-1039.

Hayudiyani, M., Saputra, B. R., Adha, M. A., \& Ariyanti, N. S. (2020). Strategi Kepala Sekolah Meningkatkan Mutu Pendidikan melalui Program Unggulan Sekolah. Jurnal Akuntabilitas Manajemen Pendidikan, 8(1), $111-118$.

Indratmoko, A., Ahmadi, K., \& Yunianto, C. (2019). Revitalisasi Pembangunan Karakter dalam Manajemen Pembelajaran Pendidikan Kewarnegaraan. Citizenship Jurnal Pancasila dan Kewarganegaraan, 7(1), 18-27.

Juharyanto, Bafadal, I., Arifin, I., Saputra, B. R., \& Adha, M. A. (2020). The Use of Conventional Communication Technology as an Effective Principal Leadership Strategy in Strengthening the Role of Multi-Stakeholder's Forum for School Quality improvement. Elementary Education Online, 19(4), 1963-1973. https://doi. org/10.17051/ilkonline.2020.762773

Lestyarini, B. (2012). Penumbuhan Semangat Kebangsaan Untuk Memperkuat Karakter Indonesia Melalui Pembelajaran Bahasa. Jurnal Pendidikan Karakter, 3, 341-354.

Maunah, B. (2015). Implementasi Pendidikan Karakter Dalam Pembentukan Kepribadian Holistik Peserta Didik. Jurnal Pendidikan Karakter, 5(1), 90-101.

Megawangi. (2010). Pengembangan Program Pendidikan Karakter Di Sekolah: Pengalaman Sekolah Karakter. Membangun Profesionalitas Insan Pendidikan Yang Berkarakter dan Berbasis Budaya, 1-8.

Mulyasa. (2013). Manajemen Pendidikan Karakter. Bumi Aksara.

Muryatama, F. (2018). Penguatan Karakter Semangat Kebangsaan Dan Cinta Tanah Air Melalui Lagu Indonesia Raya 3 Stanza Di Mim Gonilan Kartasura. Universitas Muhammadiyah Surakarta.

Pane, M. M., \& Patriana, R. (2016). The Significance of Environmental Contents in Character Education for Quality of Life. Procedia - Social and Behavioral Sciences, 222, 244-252. https://doi.org/10.1016/j. sbspro.2016.05.153

Parker, L. (2014). Religious Education for Peaceful Coexistence in Indonesia? South East Asia Research, 22(4), 487-504. https://doi.org/10.5367/sear.2014.0231

Parker, L., \& Raihani, R. (2011). Democratizing Indonesia through Education ? Community Participation in Islamic Schooling. Educational Management Administration \& Leadership, 39(6), 712-732. https://doi. org/10.1177/1741143211416389

Priyambodo, A. B. (2017). Implementasi Pendidikan Karakter Semangat Kebangsaan Dan Cinta Tanah Air Pada Sekolah Berlatar Belakang Islam Di Kota Pasuruan. Jurnal Sains Psikolog, 6(1), 9-15. 
Raihani. (2011). A Whole-School Approach: A Proposal for Education for Tolerance in Indonesia. Theory and Research in Education, 9(1), 23-39. https://doi.org/10.1177/1477878510394806

Samani. (2011). Konsep dan Model Pendidikan Karakter. PT Remaja Rosdakarya.

Wibowo, A. (2013). Manajemen Pendidikan Karakter Sekolah Konsep dan Praktik Implementasi. Pustaka Belajar. 